Article

\title{
Stimulatory Effect of Seed Priming as Pretreatment Factors on Germination and Yield Performance of Yard Long Bean (Vigna unguiculata)
}

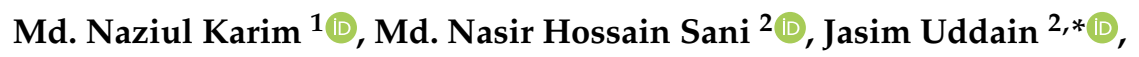 \\ Md Obyedul Kalam Azad ${ }^{3}$ (D), Md. Sazzadul Kabir ${ }^{4}$, Mohammed Saifur Rahman ${ }^{5}$, \\ Ki Young Choi ${ }^{6, *}$ and Most Tahera Naznin ${ }^{5, *}$ \\ 1 Institute of Seed Technology, Sher-e-Bangla Agricultural University, Dhaka 1207, Bangladesh; \\ nazirashed@yahoo.com \\ 2 Department of Horticulture, Sher-e-Bangla Agricultural University, Dhaka 1207, Bangladesh; \\ nsanisau@gmail.com \\ 3 Department of Bio-Health Technology, College of Biomedical Science, Kangwon National University, \\ Chuncheon 24341, Korea; azadokalam@gmail.com \\ 4 Department of Electrical and Electronic Engineering, American International University, \\ Dhaka 1229, Bangladesh; sazzadul.23@gmail.com \\ 5 Department of Biosystems and Technology, Swedish University of Agricultural Sciences, Box 103, \\ 23053 Alnarp, Sweden; morn0004@stud.slu.se \\ 6 Department of Controlled Agriculture, College of Agriculture and Life Sciences, Kangwon National \\ University, Chuncheon 24341, Korea \\ * Correspondence: uddain.jasim@gmail.com (J.U.); choiky@kangwon.ac.kr (K.Y.C.); \\ naznin.most.tahera@slu.se (M.T.N.)
}

Received: 21 November 2020; Accepted: 10 December 2020; Published: 15 December 2020

\begin{abstract}
Seed priming is a technique that can potentially facilitate rapid and consistent germination and subsequent plant growth. The present study investigates the effect of different seed priming treatments and processing times on germination and growth efficiency for the effective cultivation of Yard-long bean. Thirteen different primings were used to determine the stimulatory effect on the germination and yield performance of the Yard-long bean. The priming treatments included control (without priming); hydro priming for $12,18,24$, and $30 \mathrm{~h}$; halo priming $\left(1 \% \mathrm{CaCl}_{2}\right)$ for 12 , 18,24 , and $30 \mathrm{~h}$; and halo priming $\left(2 \% \mathrm{KNO}_{3}\right)$ for $12,18,24$, and $30 \mathrm{~h}$. Studies showing the highest level of germination $(86.66 \%)$, germination index (35.69), seedling vigor index (1833.80), number of branches (7.20), and pod yields per plant $(1836.00 \mathrm{~g})$ were recorded from halo priming with $1 \% \mathrm{CaCl}_{2}$ at $12 \mathrm{~h}$ treatment. Halo priming with $1 \% \mathrm{CaCl}_{2}$ at $12 \mathrm{~h}$ is thus considered to be a compatible priming technique for the germination of seeds and a higher yield of Yard-long bean.
\end{abstract}

Keywords: bean; pretreatment factors; seed priming; seedling growth; yield

\section{Introduction}

Uniform germination, seedling vigor, plant growth, and maturity are considered the most decisive factors that lead to successful crop establishment ensuring high productivity [1]. In this scenario, the main target of the agricultural seed industry is to boost the essential and yield-defining stage of crop cultivation by improving the germination and vigor indices of seeds. Nonetheless, poor seed vigor, as well as adverse climatic conditions following sowing, can lead to slow germination and poor seedling establishment. Low-input agriculture in developing countries at a marginal level faces a massive challenge of crop development [2]. The problem is severe in semi-arid areas because of the 
low water potential, soil crusting, and high temperature, resulting in reduced crop establishment [3]. In the face of climate change, high temperature in particular adversely affects agroecosystems [4]. Furthermore, low seed quality under field conditions may not perform consistently, and can delay germination and negatively affect seedling vigor, thus adversely affecting yield performance. Therefore, the agricultural industry seeks any reliable technique that can enhance the ability of seeds to germinate and establish rapidly and uniformly with robust crop stand, and provide higher production efficiency at diverse environmental conditions.

Seed priming is a technique for minimizing emergence time, ensuring consistent germination, and improving crop performance. It is a treatment at pre-sowing, leading to a physiological condition that makes it more useful for the seed to germinate. Priming also implies a simple procedure that hydrates seed partially in a controlled environment followed by seed drying, so that processes of germination start without a radical appearance [5]. The method is beneficial for many plants where germination and growth can restrict by adverse soil and climatic conditions. This simple pre-sowing process can enhance the emergence of radicle, pace of germination, seedling vigor, and uniform establishment by changing various physiological and metabolic activities [6]. Specific pre-hydration and priming methods reported improving the germination and synchronization of seeds [7]. Osmo-priming, halo-priming, and hydro-priming (soaking seeds in osmotic solutions) are some of the most popular priming methods. Hydro priming and halo priming have been reported to increase the germination of seedlings and their development in various plant species [8]. However, priming success depends on several physical and chemical factors such as water potential, priming duration, priming agents, and seed condition that influence subsequent crop development [9]. Therefore, the optimization of the priming technique and priming duration for a specific crop is an area worth exploring to improve crop establishment and productivity in a wide range of environmental conditions.

Yard-long bean (Vigna unguiculata L.) is one of the most popular Southeast Asian vegetables, especially in Bangladesh [10]. The Yard-long bean is highly rich in protein, vitamin A, and vitamin C, which also provide an excellent dietary source of minerals such as calcium, iron, magnesium, manganese, phosphorus, and riboflavin [11]. Yard-long bean cultivation, however, faces numerous challenges, including non-uniform and delayed germination, as well as poor seed vigor, growth, and yield [12]. Rapid, consistent, and complete germination is a pre-condition for successful vegetable crop production. However, the main problems in beans' cultivation are longer germination time, non-uniform germination, and poor emergence [13,14]. In recent years, several studies on seed priming with specific salts like $\mathrm{CaCl}_{2}$, and $\mathrm{KNO}_{3}$ reported enhanced germination of various plant species and overall growth under both normal and stress conditions. However, studies that attempted to check the response of priming on crops during the whole growing season are very limited. Additionally, most of the priming experiments are conducted on either laboratory or greenhouse trials, whereas assessment of performance in field conditions with diverse climatic conditions is scarce, particularly in the Bangladesh context.

The main objective of the current research was to study the stimulatory effect of the different primings and processing times on germination and yield performance to identify the suitable seed priming methods and optimum priming duration for successful Yard-long been cultivation.

\section{Materials and Methods}

\subsection{Plant Material and Priming Treatments}

The seeds of Yard-long bean (cv. BARI Borboti-1) were collected from the Bangladesh Agricultural Research Institute (BARI), Gazipur, Bangladesh. The priming treatments were viz. no priming, hydro priming at $12 \mathrm{~h}$, hydro priming at $18 \mathrm{~h}$, hydro priming at $24 \mathrm{~h}$, hydro priming at $30 \mathrm{~h}$, halo priming with $1 \% \mathrm{CaCl}_{2}$ at $12 \mathrm{~h}$, halo priming with $1 \% \mathrm{CaCl}_{2}$ at $18 \mathrm{~h}$, halo priming with $1 \% \mathrm{CaCl}_{2}$ at $24 \mathrm{~h}$, halo priming with $1 \% \mathrm{CaCl}_{2}$ at $30 \mathrm{~h}$, halo priming with $2 \% \mathrm{KNO}_{3}$ at $12 \mathrm{~h}$, halo priming with $2 \% \mathrm{KNO}_{3}$ at $18 \mathrm{~h}$, halo priming with $2 \% \mathrm{KNO}_{3}$ at $24 \mathrm{~h}$, and halo priming with $2 \% \mathrm{KNO}_{3}$ at 
$30 \mathrm{~h}$. The seedling was grown in the Seed Technology Laboratory, Department of Seed Technology, Sher-e-Bangla Agricultural University, Dhaka, Bangladesh, in 2017.

\subsection{Seed Priming Techniques}

For the preparation of $(1 \%)$ calcium chloride $\left(\mathrm{CaCl}_{2}\right)$ solution, $10 \mathrm{~g} \mathrm{CaCl}_{2}$ salts were placed in a measuring flask and the volume was made up to $1000 \mathrm{~mL}$ with distilled water. Similarly, a $1 \%$ potassium nitrate $\left(\mathrm{KNO}_{3}\right)$ solution was prepared by placing $10 \mathrm{~g}$ of salt into a measuring flask, and the volume was made up to $1000 \mathrm{~mL}$ with distilled water. The seeds were washed with distilled water with subsequent dipping into sodium hypochlorite $0.05 \%$ solution $(5 \mathrm{~min})$ for surface sterilization. Seeds were then dried at room temperature up to moisture content $<10 \%$ on a dry weight basis of the seeds following standard conditions for seed storage [15]. The seeds were immersed in distilled water to regulate hydro-priming, halo $\left(1 \% \mathrm{CaCl}_{2}\right)$, and halo $\left(2 \% \mathrm{KNO}_{3}\right)$ each for $12,18,24$, and $30 \mathrm{~h}$, respectively, as per treatments separately at room temperature.

\subsection{Germination Test}

Fifteen seeds were placed in Petri dishes (diameter $11 \mathrm{~cm}$ ) composed of double layers of Whatman No.1 filter paper, which were moistened with $5 \mathrm{~mL}$ distilled water up to seven days. Each priming treatment was replicated three times in a completely randomized design (CRD). The Petri dishes were placed accordingly for germination and incubated in a seed germinator under controlled conditions at $25{ }^{\circ} \mathrm{C}$ and $60 \%$ relative humidity (RH). The only disinfected seed that did not receive any priming treatment was used as control. Upon germination, seedlings were counted up to two weeks. The number of normal seedlings was interpreted according to International Seed Testing Agency (ISTA) criteria for normal seedlings [16]. The germination parameters were determined as follows.

\subsection{Total Germination Percentage (TG \%)}

The total number of treated seeds germinated in the total days was determined as a proportion of the seed numbers shown as a percentage for each procedure [17]

$\mathrm{TG}(\%)=($ Number of germinated seed/Total number of seed set for germination $) \times 100$

\subsection{Speed of Germination}

The method provided by the author of [18] was used to determine the speed of germination with the following formula:

$$
\text { Speed of germination }=\mathrm{N} 1 / \mathrm{d} 1+\mathrm{N} 2 / \mathrm{d} 2+\mathrm{N} 3 / \mathrm{d} 3+\ldots \ldots \ldots+\mathrm{Nn} / \mathrm{dn}
$$

where $\mathrm{N}=$ number of germinated seed; $\mathrm{d}=$ number of days .

\subsection{Germination Index (GI)}

As defined in the Official Seed Analyst Association [19], the germination index (GI) was calculated as follows:

$$
\text { Germination Index }=\mathrm{Gt} / \mathrm{Tt}
$$

where

$\mathrm{Gt}=$ number of seeds germinated on day $\mathrm{t}$;

$\mathrm{Tt}=$ the number of germinated seeds at time Ti. 


\subsection{Vigor Index (VI)}

The index of vigor (VI) was determined using the equation from the author of [20] from maximum germination and the length of seedlings.

$$
\mathrm{VI}=\mathrm{TG}(\%) \times \text { seedling length }(\mathrm{mm}) / 100
$$

where $\mathrm{TG}=$ total germination.

\subsection{Experimental Area, Climatic Conditions, and Soil}

The field experiment was conducted at Horticulture Research Field, Sher-e-Bangla Agricultural University, Dhaka, Bangladesh, in 2017. The study area was located at $23^{\circ} 77^{\prime} \mathrm{N}$ and $90^{\circ} 33^{\prime} \mathrm{E}$ at an altitude of $8.2 \mathrm{~m}$ above the sea level. The study area was part of the "Modhupur Tract" Agro-Ecological Area, AEZ-28. The studied soil belongs to the general type of soil and the flaky red-brown Tejgaon series terrace soil. The chemical composition of the studied soil was organic carbon $(1.28 \%)$, total $\mathrm{N}(0.09 \%)$, P (18.47 ppm), and K (0.09 mg/100 g); PH 6.14.

\subsection{Experimental Setup, Planting Time, and Management Practices}

The field trial was conducted in a randomized complete block design (RCBD) with three replications. Each block was separated by a $1.5 \mathrm{~m}$ alley. Plots were $4 \mathrm{~m}$ in length, consisting of 10 rows maintaining $25 \mathrm{~cm}$. Seeds were seeded at a depth of $3-4 \mathrm{~cm}$. In this experiment, fertilizers and manures were applied according to the recommended doses corresponding to $140 \mathrm{~kg} \mathrm{~N} \mathrm{ha}^{-1}, 60 \mathrm{~kg} \mathrm{P} \mathrm{ha}^{-1}$, and $70 \mathrm{~kg} \mathrm{~K} \mathrm{ha}^{-1}$, respectively [21]. Manual weed control, insecticide spray, and disease control practice performed when necessary. At maturity ( 80 days after germination), all the pods from each plant were hand-harvested and weighed, and seed yield was determined.

\subsection{Statistical Analysis}

Data from both experiments were collected, extracted, and tabulated. Data from the laboratory trial were subjected to one-way analysis of variance (ANOVA). All mean data were evaluated in one-way ANOVA using SPSS (version 20, SPSS Inc., Chicago, IL, USA). Comparisons of the mean data and standard error (S.E) were determined by DMRTs (Duncan's multiple range tests) at a $p \leq 0.05$ level of significance. Statistical analysis of the significance of the variance arising from the filed treatments was conducted on different plant characteristics. Means were compared at $p<0.05$ using DMRTs (Duncan's multiple range tests).

\section{Results}

\subsection{Seedling Evaluations by Different Seed Priming Treatments}

Priming treatments of seeds significantly affected the germination attributes, resulting in greater germination percentage, speed of germination, germination index, and vigor index (Table 1). All the primed seeds showed significantly higher germination percentage over the control. Among the seed priming tested, halo priming with $1 \% \mathrm{CaCl}_{2}$ at $12 \mathrm{~h}$ enhanced the germination up to $86.66 \%$ compared with the non-primed control treatment (36.66\%). Notably, the treatments hydro priming at $24 \mathrm{~h}(70 \%)$, hydro priming at $30 \mathrm{~h}(66.66 \%)$, and halo priming with $1 \% \mathrm{CaCl}_{2}$ at $24 \mathrm{~h}(66.66 \%)$ showed a moderate range of germination percentage. Similarly, various seed priming treatments showed a strong impact on the rate of the germination of the Yard-long bean. Among the treatments, the highest speed of germination (6.76) was recorded in halo priming with $1 \% \mathrm{CaCl}_{2}$ at $12 \mathrm{~h}$ treatment, which is statistically similar to hydro priming at $24 \mathrm{~h}$. Meanwhile, the lowest (1.18) speed of germination was found in non-primed treatment. 
Table 1. Effect of different seed priming treatments on germination percentage, speed of seed germination, germination index, and vigor index.

\begin{tabular}{|c|c|c|c|c|}
\hline Treatments & $\begin{array}{l}\text { Germination } \\
\text { Percentage }\end{array}$ & $\begin{array}{c}\text { Speed of } \\
\text { Germination }\end{array}$ & $\begin{array}{l}\text { Germination } \\
\text { Index (GI) }\end{array}$ & Vigor Index \\
\hline No Priming & $36.66 \pm 8.82^{d}$ & $1.18 \pm 0.14^{\mathrm{e}}$ & $22.88 \pm 0.35^{\mathrm{f}}$ & $651.53 \pm 248.73^{d}$ \\
\hline Hydro Priming at $12 \mathrm{~h}$ & $56.66 \pm 6.67 \mathrm{bc}$ & $4.60 \pm 0.51 \mathrm{bc}$ & $27.30 \pm 0.31^{\mathrm{d}}$ & $1061.80 \pm 104.44^{b c}$ \\
\hline Hydro Priming at $18 \mathrm{~h}$ & $43.33 \pm 8.82^{c}$ & $3.04 \pm 0.79^{b-d}$ & $29.70 \pm 0.61^{\mathrm{c}}$ & $913.20 \pm 175.80 \mathrm{bc}$ \\
\hline Hydro Priming at $24 \mathrm{~h}$ & $70.00 \pm 10.00^{b}$ & $5.78 \pm 0.40^{\mathrm{ab}}$ & $31.23 \pm 0.75^{b}$ & $1128.80 \pm 132.73 b c$ \\
\hline Hydro Priming at $30 \mathrm{~h}$ & $66.66 \pm 14.53^{b}$ & $4.81 \pm 1.13^{b c}$ & $29.10 \pm 0.29^{c}$ & $1067.46 \pm 41.23 b c$ \\
\hline $\begin{array}{l}\text { Halo Priming with } 1 \% \\
\qquad \mathrm{CaCl}_{2} \text { at } 12 \mathrm{~h}\end{array}$ & $86.66 \pm 3.33^{a}$ & $6.76 \pm 0.49^{\mathrm{a}}$ & $35.69 \pm 0.66^{\mathrm{a}}$ & $1833.80 \pm 99.23^{a}$ \\
\hline $\begin{array}{l}\text { Halo Priming with } 1 \% \\
\qquad \mathrm{CaCl}_{2} \text { at } 18 \mathrm{~h}\end{array}$ & $63.33 \pm 6.67^{b c}$ & $3.49 \pm 0.96^{\mathrm{cd}}$ & $30.55 \pm 0.71 \mathrm{bc}$ & $1297.60 \pm 93.17^{b}$ \\
\hline $\begin{array}{l}\text { Halo Priming with } 1 \% \\
\qquad \mathrm{CaCl}_{2} \text { at } 24 \mathrm{~h}\end{array}$ & $66.66 \pm 6.67^{b}$ & $4.66 \pm 0.91 \mathrm{bc}$ & $31.46 \pm 0.25^{b}$ & $1216.40 \pm 6.80^{b}$ \\
\hline $\begin{array}{l}\text { Halo Priming with } 1 \% \\
\qquad \mathrm{CaCl}_{2} \text { at } 30 \mathrm{~h}\end{array}$ & $60.00 \pm 5.77^{b c}$ & $4.43 \pm 0.56^{b c d}$ & $30.13 \pm 0.28^{b c}$ & $1247.00 \pm 128.16^{b}$ \\
\hline $\begin{array}{l}\text { Halo Priming with } 2 \% \\
\mathrm{KNO}_{3} \text { at } 12 \mathrm{~h}\end{array}$ & $56.66 \pm 6.67^{b c}$ & $4.71 \pm 0.94 \mathrm{bc}$ & $27.69 \pm 0.45^{d}$ & $1180.46 \pm 53.58^{b}$ \\
\hline $\begin{array}{l}\text { Halo Priming with } 2 \% \\
\mathrm{KNO}_{3} \text { at } 18 \mathrm{~h}\end{array}$ & $46.66 \pm 6.67^{c}$ & $3.17 \pm 1.45^{\mathrm{cd}}$ & $25.42 \pm 0.37^{\mathrm{e}}$ & $934.53 \pm 168.46^{b c}$ \\
\hline $\begin{array}{l}\text { Halo Priming with } 2 \% \\
\mathrm{KNO}_{3} \text { at } 24 \mathrm{~h}\end{array}$ & $43.33 \pm 8.82^{c}$ & $2.43 \pm 0.77^{\mathrm{cd}}$ & $24.01 \pm 0.25^{\mathrm{e}}$ & $954.26 \pm 236.34 \mathrm{bc}$ \\
\hline $\begin{array}{l}\text { Halo Priming with } 2 \% \\
\mathrm{KNO}_{3} \text { at } 30 \mathrm{~h}\end{array}$ & $42.66 \pm 12.02^{\mathrm{c}}$ & $1.87 \pm 0.78^{\mathrm{d}}$ & $23.69 \pm 0.32^{\mathrm{e}}$ & $858.43 \pm 268.09 b c$ \\
\hline$p$-value & 0.010 & 0.003 & 0.00 & 0.005 \\
\hline
\end{tabular}

The data represent the mean values \pm standard error. Values marked by different letters in each column is significantly different in the $t$-test $(p<0.05)$.

The priming of seed varies substantially on the Yard-long bean germination index (Table 1). All the priming treatments showed an improved germination index over the non-primed control. The maximum germination index (35.69) was recorded from halo priming with $1 \% \mathrm{CaCl}_{2}$ at $12 \mathrm{~h}$ treatment. The treatments hydro priming at $24 \mathrm{~h}$, halo priming with $1 \% \mathrm{CaCl}_{2}$ at $18 \mathrm{~h}$, halo priming with $1 \% \mathrm{CaCl}_{2}$ at $24 \mathrm{~h}$, and halo priming with $1 \% \mathrm{CaCl}_{2}$ at $30 \mathrm{~h}$ displayed a moderately improved and statistically similar germination index. On the other hand, the lowest germination index (22.88) was reported from the control treatment. The vigor index of the long bean was also influenced by the specific seed treatments. The maximum vigor index (1833.80) was observed in halo priming with $1 \%$ $\mathrm{CaCl}_{2}$ at $12 \mathrm{~h}$ treatment, whereas the lowest (651.53) vigor index was found in no priming treatment. All other treatments showed a moderate range of the vigor index and were statistically similar to each other.

The treatments for priming significantly influenced the seedling length of the Yard-long bean (Table 2). The highest seedling length $\left(26.42 \mathrm{~cm}\right.$ ) was found in halo priming with $1 \% \mathrm{CaCl}_{2}$ at $12 \mathrm{~h}$ treatment, whereas the minimum seedling length was recorded from no priming treatment. Priming treatments also substantially affected the shooting length of Yard-long beans (Table 2). All the priming treatments showed enhanced shoot length in comparison with the control. The maximum shoot length $(15.56 \mathrm{~cm})$ was achieved from the treatment halo priming with $1 \% \mathrm{CaCl}_{2}$ at $12 \mathrm{~h}$ treatment. A moderately increased seedling shoot length was recorded from the treatment hydro priming at $24 \mathrm{~h}$ $(14.01 \mathrm{~cm})$, halo priming with $1 \% \mathrm{CaCl}_{2}$ at $18 \mathrm{~h}$ treatment $(13.99 \mathrm{~cm})$, and halo priming with $1 \% \mathrm{CaCl}_{2}$ at $24 \mathrm{~h}$ treatment $(13.97 \mathrm{~cm})$, which were statistically alike. It is evident that, compared with other priming treatments, all the halo priming treatments with $\mathrm{CaCl}_{2}$ showed better results in incrementing the shoot length of the Yard-long bean. On the other hand, the minimum shoot length $(10.75 \mathrm{~cm})$ was recorded in the no priming treatment. 
Table 2. Effect of different seed priming treatments on shoot length, root length, and the length of seedling.

\begin{tabular}{|c|c|c|c|}
\hline Treatments & Seedling Length $(\mathrm{cm})$ & Shoot Length $(\mathrm{cm})$ & Root Length (cm) \\
\hline No Priming & $17.72 \pm 3.91^{\mathrm{e}}$ & $10.75 \pm 2.80^{\mathrm{e}}$ & $6.97 \pm 1.11^{d}$ \\
\hline Hydro Priming at $12 \mathrm{~h}$ & $20.36 \pm 1.11^{d}$ & $11.56 \pm 0.88^{\mathrm{d}}$ & $8.88 \pm 0.28^{\mathrm{cd}}$ \\
\hline Hydro Priming at $18 \mathrm{~h}$ & $21.25 \pm 1.77^{b c d}$ & $11.70 \pm 1.35^{\mathrm{cd}}$ & $10.18 \pm 0.48^{a b}$ \\
\hline Hydro Priming at $24 \mathrm{~h}$ & $25.80 \pm 0.81^{\mathrm{a}}$ & $14.01 \pm 1.02^{b}$ & $11.79 \pm 0.50^{\mathrm{a}}$ \\
\hline Hydro Priming at $30 \mathrm{~h}$ & $22.08 \pm 1.33 \mathrm{bcd}$ & $12.87 \pm 0.45^{\mathrm{bcd}}$ & $9.21 \pm 0.89 b c$ \\
\hline $\begin{array}{l}\text { Halo Priming with } 1 \% \\
\qquad \mathrm{CaCl}_{2} \text { at } 12 \mathrm{~h}\end{array}$ & $26.42 \pm 0.74^{\mathrm{a}}$ & $15.56 \pm 0.16^{\mathrm{a}}$ & $10.86 \pm 0.78^{a b}$ \\
\hline $\begin{array}{l}\text { Halo Priming with } 1 \% \\
\qquad \mathrm{CaCl}_{2} \text { at } 18 \mathrm{~h}\end{array}$ & $23.09 \pm 0.42^{b}$ & $13.99 \pm 0.05^{b}$ & $9.10 \pm 0.45^{b c}$ \\
\hline $\begin{array}{l}\text { Halo Priming with } 1 \% \\
\qquad \mathrm{CaCl}_{2} \text { at } 24 \mathrm{~h}\end{array}$ & $22.67 \pm 0.77 b c$ & $13.97 \pm 0.52^{b}$ & $8.70 \pm 0.45^{\mathrm{cd}}$ \\
\hline $\begin{array}{l}\text { Halo Priming with } 1 \% \\
\qquad \mathrm{CaCl}_{2} \text { at } 30 \mathrm{~h}\end{array}$ & $21.04 \pm 1.79 \mathrm{~cd}$ & $13.51 \pm 1.01 \mathrm{bc}$ & $7.53 \pm 0.89$ cde \\
\hline $\begin{array}{l}\text { Halo Priming with } 2 \% \\
\mathrm{KNO}_{3} \text { at } 12 \mathrm{~h}\end{array}$ & $21.53 \pm 0.77 \mathrm{bcd}$ & $12.48 \pm 0.26^{\mathrm{cd}}$ & $9.05 \pm 0.62 b c$ \\
\hline $\begin{array}{l}\text { Halo Priming with } 2 \% \\
\mathrm{KNO}_{3} \text { at } 18 \mathrm{~h}\end{array}$ & $20.56 \pm 2.76^{d}$ & $12.03 \pm 2.11^{\mathrm{cd}}$ & $8.53 \pm 0.72^{\mathrm{cd}}$ \\
\hline $\begin{array}{l}\text { Halo Priming with } 2 \% \\
\mathrm{KNO}_{3} \text { at } 24 \mathrm{~h}\end{array}$ & $20.39 \pm 4.11^{d}$ & $11.96 \pm 2.82 \mathrm{~cd}$ & $8.43 \pm 1.35^{\mathrm{cd}}$ \\
\hline $\begin{array}{l}\text { Halo Priming with } 2 \% \\
\mathrm{KNO}_{3} \text { at } 30 \mathrm{~h}\end{array}$ & $17.81 \pm 1.21^{\mathrm{e}}$ & $11.21 \pm 0.90^{\mathrm{d}}$ & $6.60 \pm 0.33^{d}$ \\
\hline$p$-value & 0.024 & 0.042 & 0.029 \\
\hline
\end{tabular}

The data represent the mean values \pm standard error. Values marked by different letters in each column is significantly different in the $t$-test $(p<0.05)$.

Similarly to shoot length, the root length of the Yard-long bean was significantly affected by various priming treatments (Table 2). The longest root $(11.79 \mathrm{~cm})$ was recorded from the hydro priming treatment at $24 \mathrm{~h}$, followed by the treatment halo priming with $1 \% \mathrm{CaCl}_{2}$ at $12 \mathrm{~h}$ treatment $(10.86 \mathrm{~cm})$ and hydro priming at $18 \mathrm{~h}(10.18 \mathrm{~cm})$, which were statistically alike. However, the shortest seedling root $(6.60 \mathrm{~cm})$ was recorded from the treatment halo priming with $2 \% \mathrm{KNO}_{3}$ at $30 \mathrm{~h}$.

Specific seed priming treatments substantially affected the fresh weight of the seedling for Yard-long beans (Table 3). The fresh weight of seedling was higher $(1.43 \mathrm{~g})$ in halo priming with $1 \%$ $\mathrm{CaCl}_{2}$ at $12 \mathrm{~h}$ treatment, whereas the lowest $(0.31 \mathrm{~g})$ fresh weight of seedling was found in no priming treatment. The treatment hydro priming at $18 \mathrm{~h}(0.99 \mathrm{~g})$ showed the moderate fresh weight of seedlings. However, there were no major differences in the dry weight of the Yard-long beans for seed priming treatments (Table 3$)$. The maximum dry weight $(0.24 \mathrm{~g})$ of seedling was achieved in halo priming with $1 \% \mathrm{CaCl}_{2}$ at $18 \mathrm{~h}$ treatment, and the lowest $(0.10 \mathrm{~g})$ dry weight of seedling was found in halo priming with $1 \% \mathrm{CaCl}_{2}$ at $24 \mathrm{~h}$ treatment. All other priming treatments displayed a statistically similar reflection for the parameter of dry weight of seedling.

\subsection{Seed Priming Effects on Plant Growth and Yield Contributing Characters of Yard-Long Bean}

Various seed priming treatments had a significant influence on the branch number of the Yard-long bean plant (Table 3). The maximum number (7.20) of branches was recorded from the treatment halo priming with $1 \% \mathrm{CaCl}_{2}$ at $12 \mathrm{~h}$ treatment. The treatment hydro priming at $12 \mathrm{~h}(6.67)$, hydro priming

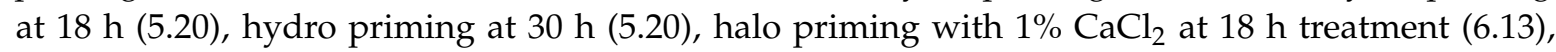
halo priming with $1 \% \mathrm{CaCl}_{2}$ at $30 \mathrm{~h}$ treatment (6.07), and T9 halo priming with $2 \% \mathrm{KNO}_{3}$ at $12 \mathrm{~h}$ treatment (6.80) showed a statistically similar reflection in enhancing the number of branches per plant, whereas the lowest (4.13) branch number of the plant was found in halo priming with $1 \% \mathrm{CaCl}_{2}$ at $24 \mathrm{~h}$ treatment. The initial flowering of the Yard-long bean plant was significantly influenced by various seed treatments (Table 3). The first flowering of the plant was delayed (49.66 days) in T11 halo priming 
with $2 \% \mathrm{KNO}_{3}$ at $24 \mathrm{~h}$ treatment. Meanwhile, earlier (40 days) first flowering of the plant was found in hydro priming at $12 \mathrm{~h}$ treatment (Table 3 ).

Table 3. Effect of different seed priming treatments on fresh weight of seedling, dry weight of seedling, branch number per plant, and first flowering of the plant.

\begin{tabular}{|c|c|c|c|c|}
\hline Treatments & $\begin{array}{l}\text { Fresh Weight of } \\
\text { Seedling (g) }\end{array}$ & $\begin{array}{l}\text { Dry Weight of } \\
\text { Seedling (g) }\end{array}$ & $\begin{array}{c}\text { Branch } \\
\text { Number/Plant }\end{array}$ & $\begin{array}{c}\text { First Flowering } \\
\text { (Days) }\end{array}$ \\
\hline No Priming & $0.31 \pm 0.10^{\mathrm{e}}$ & $0.13 \pm 0.05^{b}$ & $4.47 \pm 0.48^{d}$ & $41.00 \pm 1.00 \mathrm{~cd}$ \\
\hline Hydro Priming at $12 \mathrm{~h}$ & $0.87 \pm 0.21^{b c}$ & $0.22 \pm 0.04^{\mathrm{a}}$ & $6.67 \pm 1.03^{b}$ & $40.00 \pm 1.15^{\mathrm{d}}$ \\
\hline Hydro Priming at $18 \mathrm{~h}$ & $0.99 \pm 0.08^{b}$ & $0.22 \pm 0.06^{\mathrm{a}}$ & $5.20 \pm 1.71 b c$ & $43.00 \pm 0.58^{b-d}$ \\
\hline Hydro Priming at $24 \mathrm{~h}$ & $0.88 \pm 0.09 b c$ & $0.22 \pm 0.02^{a}$ & $4.73 \pm 0.57^{\mathrm{b}-\mathrm{d}}$ & $47.00 \pm 1.73^{\mathrm{ab}}$ \\
\hline Hydro Priming at $30 \mathrm{~h}$ & $0.67 \pm 0.07 b c$ & $0.19 \pm 0.03^{a b}$ & $5.20 \pm 0.23 b c$ & $47.33 \pm 1.76^{\mathrm{a}}$ \\
\hline $\begin{array}{l}\text { Halo Priming with } 1 \% \\
\qquad \mathrm{CaCl}_{2} \text { at } 12 \mathrm{~h}\end{array}$ & $1.43 \pm 0.08^{a}$ & $0.17 \pm 0.02^{\mathrm{ab}}$ & $7.20 \pm 0.12^{a}$ & $45.33 \pm 1.00^{a-c}$ \\
\hline $\begin{array}{l}\text { Halo Priming with } 1 \% \\
\qquad \mathrm{CaCl}_{2} \text { at } 18 \mathrm{~h}\end{array}$ & $0.76 \pm 0.18^{b c}$ & $0.24 \pm 0.02^{a}$ & $6.13 \pm 0.41^{b c}$ & $43.33 \pm 2.40^{b-d}$ \\
\hline $\begin{array}{l}\text { Halo Priming with } 1 \% \\
\qquad \mathrm{CaCl}_{2} \text { at } 24 \mathrm{~h}\end{array}$ & $0.40 \pm 0.09^{d}$ & $0.10 \pm 0.01^{b}$ & $4.13 \pm 0.68^{\mathrm{d}}$ & $47.33 \pm 0.67^{a b}$ \\
\hline $\begin{array}{l}\text { Halo Priming with } 1 \% \\
\qquad \mathrm{CaCl}_{2} \text { at } 30 \mathrm{~h}\end{array}$ & $0.58 \pm 0.02^{\mathrm{cd}}$ & $0.14 \pm 0.01 \mathrm{ab}$ & $6.07 \pm 0.29 b c$ & $45.00 \pm 1.53 \mathrm{bc}$ \\
\hline $\begin{array}{l}\text { Halo Priming with } 2 \% \\
\mathrm{KNO}_{3} \text { at } 12 \mathrm{~h}\end{array}$ & $0.67 \pm 0.11^{b c}$ & $0.15 \pm 0.02^{\mathrm{ab}}$ & $6.80 \pm 0.31^{b}$ & $41.33 \pm 0.67^{\mathrm{cd}}$ \\
\hline $\begin{array}{l}\text { Halo Priming with } 2 \% \\
\mathrm{KNO}_{3} \text { at } 18 \mathrm{~h}\end{array}$ & $0.52 \pm 0.05^{\mathrm{c}-\mathrm{e}}$ & $0.14 \pm 0.02^{b}$ & $5.80 \pm 0.42^{\mathrm{cd}}$ & $43.00 \pm 1.53^{b-d}$ \\
\hline $\begin{array}{l}\text { Halo Priming with } 2 \% \\
\mathrm{KNO}_{3} \text { at } 24 \mathrm{~h}\end{array}$ & $0.52 \pm 0.13^{c-e}$ & $0.14 \pm 0.04^{b}$ & $4.53 \pm 0.58^{\mathrm{cd}}$ & $49.66 \pm 1.45^{a}$ \\
\hline $\begin{array}{l}\text { Halo Priming with } 2 \% \\
\mathrm{KNO}_{3} \text { at } 30 \mathrm{~h}\end{array}$ & $0.67 \pm 0.05^{\mathrm{cd}}$ & $0.14 \pm 0.01^{b}$ & $4.67 \pm 0.41^{\mathrm{cd}}$ & $45.33 \pm 0.88^{a-c}$ \\
\hline$p$-value & 0.000 & 0.055 & 0.050 & 0.001 \\
\hline
\end{tabular}

The data represent the mean values \pm standard error. Values marked by different letters in each column is significantly different in the $t$-test $(p<0.05)$.

There were significant differences in Yard-long bean pod length in the priming treatments (Table 4). The maximum pod length $\left(52.47 \mathrm{~cm}\right.$ ) was recorded in the treatment halo priming with $1 \% \mathrm{CaCl}_{2}$ at $12 \mathrm{~h}$ treatment, and the minimum $\left(40.08 \mathrm{~cm}\right.$ ) pod length was observed in halo priming with $2 \% \mathrm{KNO}_{3}$ at $30 \mathrm{~h}$ treatment (Table 4). Various seed priming treatments significantly influenced pod weight for the Yard-long bean (Table 4). The treatment halo priming with $1 \% \mathrm{CaCl}_{2}$ at $12 \mathrm{~h}$ showed a significantly higher pod weight $(24.93 \mathrm{~g})$. The lowest $(10.93 \mathrm{~g})$ pod weight was found in no priming treatment. A similar kind of reflection is also observed in terms of the total number of pods per Yard-long bean, where halo priming with $1 \% \mathrm{CaCl}_{2}$ at $12 \mathrm{~h}$ treatment showed a significantly higher numbers of pods over all other priming treatments (Table 4). The total pod number per plant was the highest (73.67) in halo priming with $1 \% \mathrm{CaCl}_{2}$ at $12 \mathrm{~h}$ treatment. The lowest (16.00) total pod number per plant was found in no priming treatment. The treatments halo priming with $2 \% \mathrm{KNO}_{3}$ at $12 \mathrm{~h}$ treatment (62.00), halo priming with $1 \% \mathrm{CaCl}_{2}$ at $30 \mathrm{~h}$ treatment (56.33), and halo priming with $1 \% \mathrm{CaCl}_{2}$ at $18 \mathrm{~h}$ treatment (61.00) showed a moderate total pod number per plant and were statistically similar to each other.

Priming treatment significantly influenced the 100-seed weight of the Yard-long bean (Table 4). The treatment halo priming with $1 \% \mathrm{CaCl}_{2}$ at $12 \mathrm{~h}$ showed a significantly higher 100-seed weight $(16.37 \mathrm{~g})$. The lowest $(8.53 \mathrm{~g}) 100$-seed weight was found in no priming treatment.

The yield per plant of Yard-long bean differed significantly as a result of the application of various seed priming treatments (Figure 1). All the priming treatments showed enhanced yield per plant in comparison with the non-primed control. Among the priming treatments, halo priming with $1 \% \mathrm{CaCl}_{2}$ at $12 \mathrm{~h}$ treatment showed a significantly higher pod yield over all other treatments. The highest pod yield per plant (1836.00 g) was recorded in halo priming with $1 \% \mathrm{CaCl}_{2}$ at $12 \mathrm{~h}$ treatment, whereas the 
lowest $(174.88 \mathrm{~g}$ ) yield per plant was found in no priming treatment. The treatments halo priming with $1 \% \mathrm{CaCl}_{2}$ at $18 \mathrm{~h}(1152.29 \mathrm{~g})$, T8 halo priming with $1 \% \mathrm{CaCl}_{2}$ at $30 \mathrm{~h}(1175.61 \mathrm{~g})$, and T9 halo priming with $2 \% \mathrm{KNO}_{3}$ at $12 \mathrm{~h}$ treatment (1115.36 g) displayed a statistically similar yield.

Table 4. Effect of different seed priming treatments on pod length, pod weight, total pod number per plant, and 100-seed weight.

\begin{tabular}{|c|c|c|c|c|}
\hline Treatments & $\begin{array}{l}\text { Pod Length } \\
\text { (cm) }\end{array}$ & $\begin{array}{l}\text { Pod Weight } \\
\text { (g) }\end{array}$ & $\begin{array}{c}\text { Total Pod } \\
\text { Number/Plant }\end{array}$ & $\begin{array}{l}100 \text { Seed Weight } \\
\text { (g) }\end{array}$ \\
\hline No Priming & $49.43 \pm 3.25^{b}$ & $10.93 \pm 0.90^{\mathrm{d}}$ & $16.00 \pm 2.08 \mathrm{~g}$ & $8.53 \pm 0.58^{c}$ \\
\hline Hydro Priming at $12 \mathrm{~h}$ & $46.55 \pm 2.70 \mathrm{bc}$ & $17.13 \pm 1.88^{b-d}$ & $45.33 \pm 2.91^{\mathrm{c}}$ & $11.30 \pm 0.61^{b c}$ \\
\hline Hydro Priming at $18 \mathrm{~h}$ & $42.62 \pm 4.59^{c}$ & $16.73 \pm 1.07^{\mathrm{b}-\mathrm{d}}$ & $37.00 \pm 6.03 \mathrm{de}$ & $12.07 \pm 0.84^{b}$ \\
\hline Hydro Priming at $24 \mathrm{~h}$ & $51.57 \pm 0.76^{\mathrm{ab}}$ & $22.98 \pm 0.53^{b}$ & $27.33 \pm 2.73 \mathrm{fg}$ & $9.67 \pm 0.50 b c$ \\
\hline Hydro Priming at $30 \mathrm{~h}$ & $42.99 \pm 3.99^{c}$ & $15.53 \pm 0.96^{\mathrm{cd}}$ & $22.33 \pm 5.78 \mathrm{fg}$ & $11.63 \pm 1.67^{b}$ \\
\hline $\begin{array}{l}\text { Halo Priming with } 1 \% \\
\qquad \mathrm{CaCl}_{2} \text { at } 12 \mathrm{~h}\end{array}$ & $52.47 \pm 0.69^{a}$ & $24.93 \pm 1.10^{\mathrm{a}}$ & $73.67 \pm 2.96^{a}$ & $16.37 \pm 0.92^{\mathrm{a}}$ \\
\hline $\begin{array}{l}\text { Halo Priming with } 1 \% \\
\qquad \mathrm{CaCl}_{2} \text { at } 18 \mathrm{~h}\end{array}$ & $47.05 \pm 4.10^{b c}$ & $18.89 \pm 1.78^{b c}$ & $61.00 \pm 1.73^{b}$ & $10.67 \pm 0.78^{b c}$ \\
\hline $\begin{array}{l}\text { Halo Priming with } 1 \% \\
\qquad \mathrm{CaCl}_{2} \text { at } 24 \mathrm{~h}\end{array}$ & $48.36 \pm 1.67^{b c}$ & $19.13 \pm 0.75^{b c}$ & $39.67 \pm 3.18^{c d}$ & $11.67 \pm 1.04^{b}$ \\
\hline $\begin{array}{l}\text { Halo Priming with } 1 \% \\
\qquad \mathrm{CaCl}_{2} \text { at } 30 \mathrm{~h}\end{array}$ & $52.13 \pm 3.42^{\mathrm{a}}$ & $20.87 \pm 2.65^{b c}$ & $56.33 \pm 5.21^{b}$ & $10.27 \pm 0.91^{b c}$ \\
\hline $\begin{array}{l}\text { Halo Priming with } 2 \% \\
\mathrm{KNO}_{3} \text { at } 12 \mathrm{~h}\end{array}$ & $47.09 \pm 4.88^{b c}$ & $18.00 \pm 4.21^{\mathrm{cd}}$ & $62.00 \pm 2.52^{b}$ & $11.80 \pm 1.27^{b}$ \\
\hline $\begin{array}{l}\text { Halo Priming with } 2 \% \\
\mathrm{KNO}_{3} \text { at } 18 \mathrm{~h}\end{array}$ & $46.81 \pm 0.81 \mathrm{bc}$ & $15.18 \pm 0.82^{\mathrm{cd}}$ & $39.00 \pm 1.15^{\mathrm{cd}}$ & $10.97 \pm 0.87^{b c}$ \\
\hline $\begin{array}{l}\text { Halo Priming with } 2 \% \\
\mathrm{KNO}_{3} \text { at } 24 \mathrm{~h}\end{array}$ & $45.29 \pm 2.88^{b c}$ & $16.10 \pm 3.40^{\mathrm{cd}}$ & $31.67 \pm 5.49$ def & $12.37 \pm 0.47^{b}$ \\
\hline $\begin{array}{l}\text { Halo Priming with } 2 \% \\
\mathrm{KNO}_{3} \text { at } 30 \mathrm{~h}\end{array}$ & $40.08 \pm 7.14^{c}$ & $13.80 \pm 3.35^{\mathrm{cd}}$ & $31.33 \pm 2.40$ def & $10.63 \pm 0.49 b c$ \\
\hline$p$-value & 0.421 & 0.008 & 0.000 & 0.001 \\
\hline
\end{tabular}

The data represent the mean values \pm standard error. Values marked by different letters in each column is significantly different in the $t$-test $(p<0.05)$.

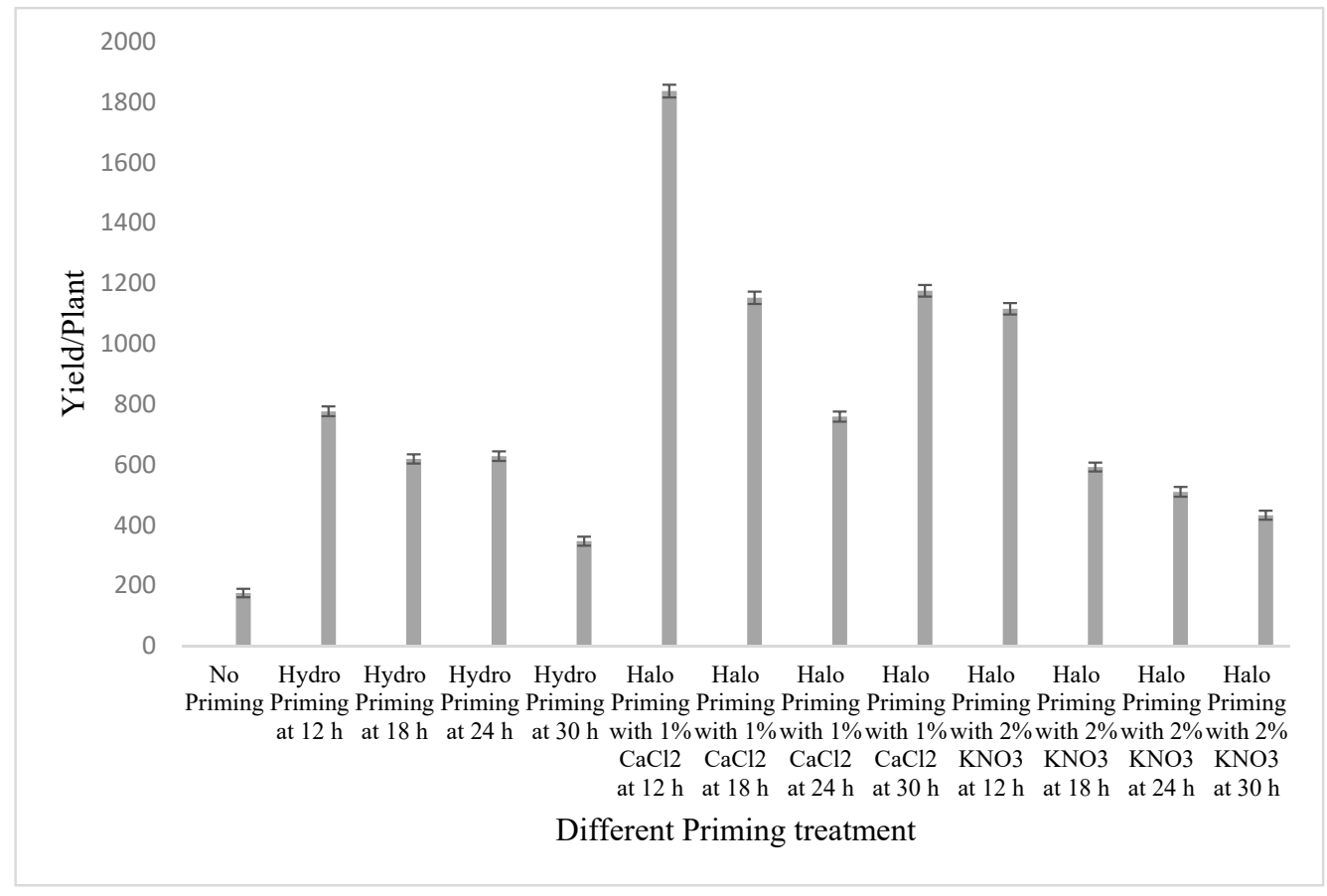

Figure 1. Yield per plant of Yard-long bean as influenced by different seed priming treatments. 


\subsection{Relationship with the Germination of Different Seedling Tests of Yard-Long Bean}

The analysis by measuring the correlation coefficients for the Yard-long bean was conducted for plant biometric indices that rely on productivity. The correlation function calculated the degree of interrelation between the variables and the effect on overall productivity. The study of the correlation coefficient indicators revealed a strong positive correlation between germination and the speed of germination $\left(R^{2}=0.8807\right)$, between the germination and germination index $\left(R^{2}=0.8285\right)$, and between the germination and vigor index $\left(R^{2}=0.8086\right)$ of the Yard-long bean (Figures $\left.2-4\right)$. The speed of germination was closest to germination, and improved germination means higher, steady sowing and higher Yard-long bean yields. These results indicated that germination (\%) increased positively in the above characteristics.

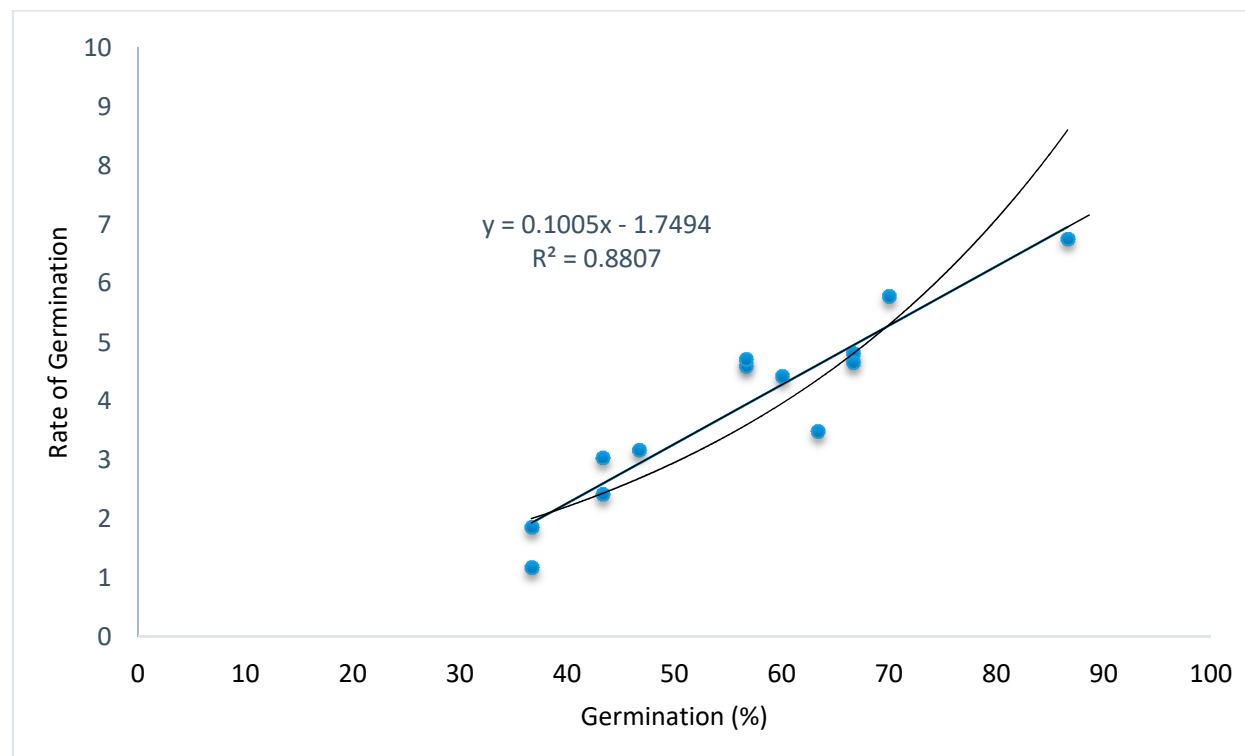

Figure 2. Relationship between the speed of germination and germination (\%) of the Yard-long bean.

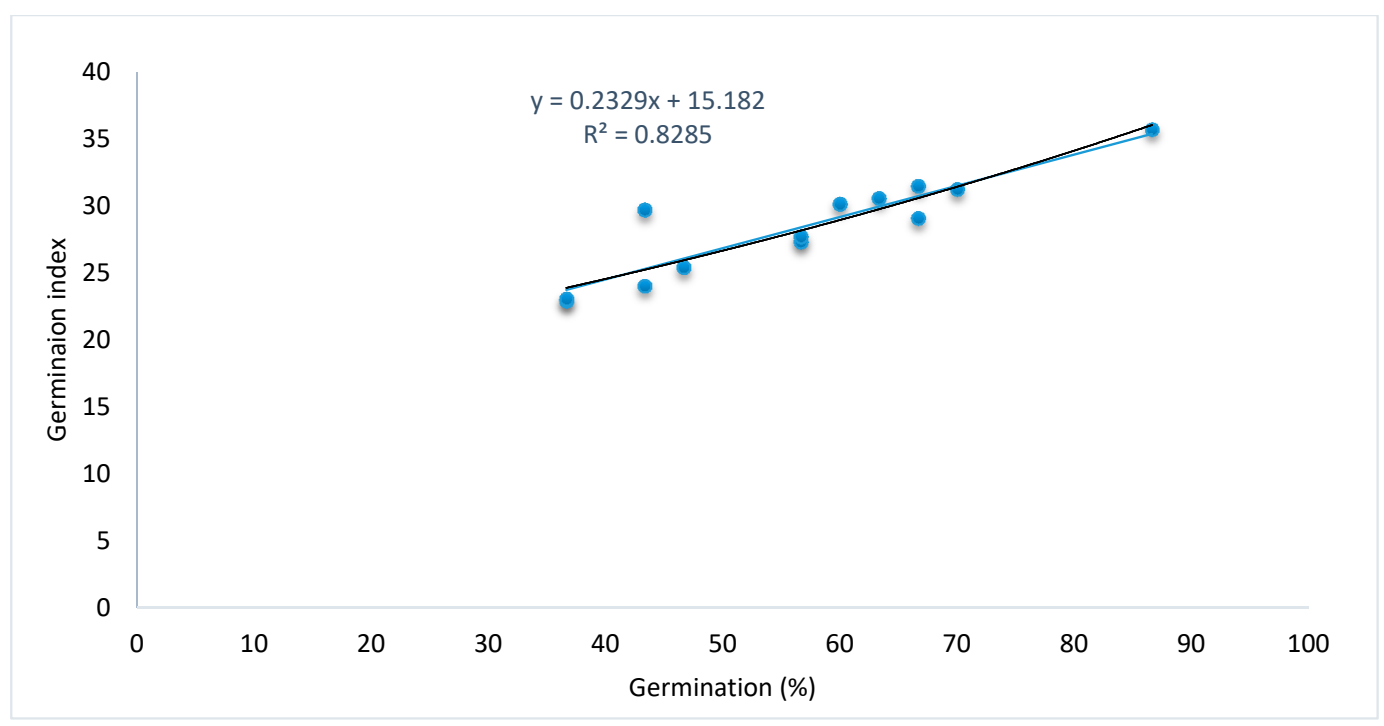

Figure 3. Relationship between the germination index and germination (\%) of the Yard-long bean. 


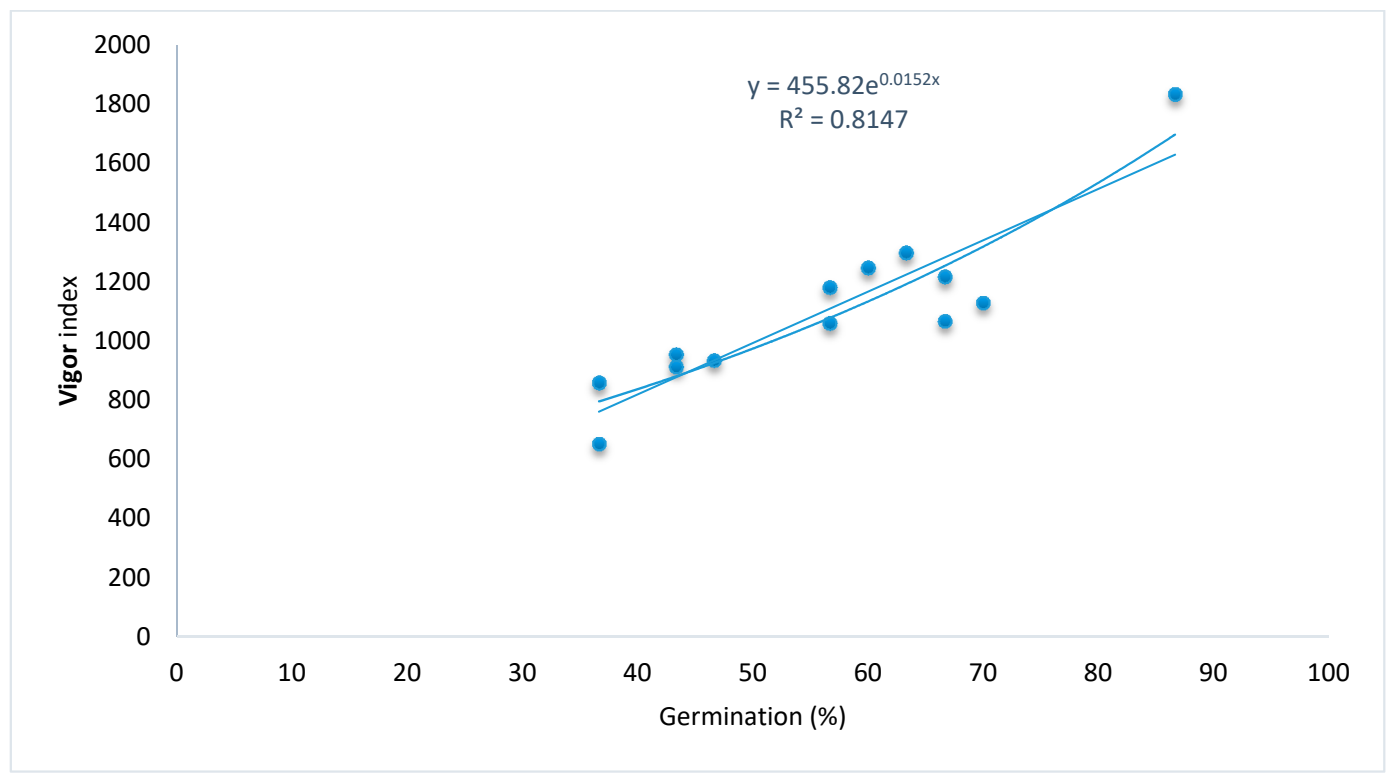

Figure 4. Relationship between the vigor index and germination (\%) of the Yard-long bean.

\section{Discussion}

Seed germination and seedling growth are two critical phases of the plant life cycle [22]. Seed priming methods influenced the seed germination process by increasing the speed and reliability of germination. Increased germination, uniformity of germination, and sometimes greater total germination rate are widely reported in the primed seed [11]. Many treatments for pre-hydration or priming have been used to improve the seed germination rate and synchronization of seeds [23]. The authors of [24] found that halo priming significantly improved the speed of germination, growth, seed germination index, root, and seedling dry weight in comparison with other seed treatments. Our current study reveals similar trends in $\mathrm{T}_{5}=$ halo priming $\left(1 \% \mathrm{CaCl}_{2}\right)$ at $12 \mathrm{~h}$, which significantly enhanced different germination indices such as germination percentage, the pace of germination, germination index, as well as vigor index of the Yard-long bean. The enhanced germination indices can be the result of the stimulated starch metabolism that set off earlier emergence and contributes to the vigorous seedling growth [25]. $\mathrm{Ca}^{2+}$ is widely reported as a prime regulator of plant growth and development [26]. $\mathrm{Ca}^{2+}$ plays a key role in maintaining cell membrane structure and function, thus providing structural integrity that is especially vital for germinating seed [27]. Furthermore, the activity of certain phosphatase and kinase enzymes involved in signal translation during germination is modulated by calcium [28]. The improved germination indices were also confirmed by the authors of [29], who noted that bean halo priming had a significant influence on seedling parameters, including dry seedling weight, rates, and germination periods under water stress conditions. In conformity, our current study also found enhanced seedling fresh and dry weight as a result of halo priming treatment in the Yard-long bean.

Direct seed priming effects on all plants can lead to improved seedling, stronger plants, greater drought tolerance, earlier flora, earlier harvesting, and increased grain yield [30-32]. Our current study noted significantly enhanced vegetative and reproductive attributes of the Yard-long bean with halo priming $\left(1 \% \mathrm{CaCl}_{2}\right)$ at $12 \mathrm{~h}$ in terms of the highest number of branches, pods per plant, pod yield, and seed weight. This increase might be caused by the metabolic improvements with halo priming that contributed to better germination, growth, and yield performance. Halo priming of seeds minimizes the emergence period and provides protection against environmental stresses, boosting uniform establishment with improved yield [33]. Halo primed seeds trigger earlier emergence, leading to energetic starts, which favor the completion of other phonological events, and in time lead to earlier flowering [34], which is also reflected in our current study. The result is in conformity 
with those of the authors of [35], who reported that halo priming improves growth performance by certain biochemical and physiological changes. Seed priming improved growth, earlier flowering, tolerance capacity, as well as yield of maize [36]. Furthermore, earlier crop establishment with vigorous growth minimizes weed competition, which facilitates increased water and nutrient absorption, resulting in a higher number of branches and yield [37]. Increased yield in the current study might be the collective response of vigorous growth and net assimilation, resulting in a higher number of branches and pods. Halo priming has been reported to favor the partitioning of dry matter to the developing pods boosting the yield of Linola (Linum usitatissimum L.) [34]. Furthermore, our regression study revealed that the speed of germination was closest to germination and that improved germination means higher, steady stand and higher yard-long bean yields. Our study also highlights that the duration of halo-priming has a significant influence on germination indices. With increasing duration of halo priming, the germination parameter decreased. Soaking in $\mathrm{CaCl}_{2}$ for a prolonged duration may lead to excessive cell wall loosening by $\mathrm{Cl}_{2}$, resulting in an adverse effect on the seed structural integrity and biochemical process. The volume of water, duration of priming, and temperature have been reported as vital factors that influence the result of priming to a large extent [38]. Therefore, further study at the molecular level is required to justify how the priming duration affects physiochemical changes of seeds during emergence.

The beneficial effects of seed priming on several field crops such as rice, sweet corn, mug bean, barley, lentil, and cucumber have been demonstrated [39]. However, germination and growth efficacy of priming agents vary in different crops [40]. In conformity, the authors of [38] reported that hydro priming did not improve China aster (Callistephus chinensis L.) seed germination capacity and germination percentage. That could be one possible reason for the higher efficiency of halo priming over other priming treatments in the Yard-long bean under the current study. Furthermore, under field circumstances, all priming treatments do not always express a significant advantage [41]. Under field condition, seedlings are exposed to a complex environment and become vulnerable to several stresses. Halo priming has been widely reported to mitigate the adverse effect of drought and salinity stress in many crops through enhancing the antioxidant system and accumulation of stress responsive proteins [34,42]. Consistent with this, our study showed improved performance of the Yard-long bean in field conditions over other primed treatments. Moreover, where inadequate priming conditions can cause degradation of the protective proteins, all priming protocols may not result in significant germination and growth [43]. Therefore, halo priming is a simple and cheap farming technique that, because of better synchrony between emergence and crop establishment, can be recommended to farmers in various environmental conditions for optimum germination, better growth, and yield performance of the Yard-long bean.

\section{Conclusions}

The current experiment concludes that seed priming, in particular halo priming, played a vital role in Yard-long bean growth and yield performance. Among the priming treatments, halo priming 1\% $\mathrm{CaCl}_{2}$ at $12 \mathrm{~h}$ showed improved germination, growth, and yield performance compared with the other seed priming treatments. Hence, seeds priming with $1 \% \mathrm{CaCl}_{2}$ for $12 \mathrm{~h}$ is an effective seed priming technique for improving germination attributes of vegetative growth and yield performance of the Yard-long bean. This method can easily be utilized to grow vegetables by all farmers of both urban and local areas in Bangladesh, as all materials are cheap in cost and have simple processing technology.

Author Contributions: This work was carried out in collaboration between all authors. J.U. and M.N.H.S. designed the study, performed the statistical analysis, interpreted the data, and wrote the draft of the manuscript. M.N.K. and M.N.H.S. performed the experiment, collected the data, and managed the literature searches. M.O.K.A., M.S.K., M.S.R., K.Y.C. and M.T.N. critically reviewed and finalized the manuscript. All authors carefully read and approved the final version of the manuscript.

Funding: This project was funded by the Ministry of Science \& Technology (Grant number: NST-128), Bangladesh. 
Acknowledgments: This project was funded by the Ministry of Science \& Technology, Bangladesh, and research facilities were provided by Sher-e-Bangla Agricultural University, Dhaka, Bangladesh.

Conflicts of Interest: The authors declare that there is no conflict of interest.

\section{References}

1. Finch-Savage, W.E.; Bassel, G.W. Seed vigour and crop establishment: Extending performance beyond adaptation. J. Exp. Bot. 2016, 67, 567-591. [CrossRef] [PubMed]

2. Tittonell, P.; Giller, K.E. When yield gaps are poverty traps: The paradigm of ecological intensification in African smallholder agriculture. Field Crops Res. 2013, 143, 76-90. [CrossRef]

3. Aune, J.B.; Coulibaly, A.; Giller, K.E. Precision farming for increased land and labour productivity in semi-arid West Africa. A review. Agron. Sustain. Dev. 2017, 37, 16. [CrossRef]

4. Knox, J.W.; Hess, T.; Daccache, A.; Wheeler, T. Climate change impacts on crop productivity in Africa and South Asia. Environ. Res. Lett. 2012, 7, 034032. [CrossRef]

5. Paparella, S.; Araújo, S.S.; Rossi, G.; Wijayasinghe, M.; Carbonera, D.; Balestrazzi, A. Seed priming: State of the art and new perspectives. Plant Cell Rep. 2015, 34, 1281-1293. [CrossRef]

6. Eisvand, H.R.; Shahrosvand, S.; Zahedi, B.; Heidari, S.; Afrougheh, S. Effects of hydro-priming and hormonal priming by gibberellin and salicylic acid on seed and seedling quality of carrot (Daucus carota var. sativus). Iran. J. Plant Physiol. 2011, 1, 233-239.

7. Bradford, K.J.; Bradford, K.J.; Bradford, K.; Bradford, K.; Bradford, K.P.; Bradford, D. Manipulation of seed water relations via osmotic priming to improve germination under stress conditions. HortScience 1986, $21,1105-1112$.

8. Afzal, I.; Basra, S.A.; Iqbal, A. The effects of seed soaking with plant growth regulators on seedling vigor of wheat under salinity stress. J. Stress Physiol. Biochem. 2005, 1, 6-14.

9. Hussain, S.; Zheng, M.; Khan, F.; Khaliq, A.; Fahad, S.; Peng, S.; Nie, L. Benefits of rice seed priming are offset permanently by prolonged storage and the storage conditions. Sci. Rep. 2015, 5, 1-12. [CrossRef]

10. Asian Vegetable Research Development Center (AVRDC) 2015. How to Grow Yard Long Bean. Available online: http://203.64.245.61/web_crops/indigenous/SI-yard_long_bean.pdf (accessed on 11 September 2020).

11. Basra, S.M.A.; Farooq, M.; Tabassam, R.; Ahmad, N. Physiological and biochemical aspects of pre-sowing seed treatments in fine rice (Oryza sativa L.). Seed Sci. Technol. 2005, 33, 623-628. [CrossRef]

12. Rashid, M.M. Sabji Biggan, 1st ed.; Bangla Academy: Dhaka, Bangladesh, 1993; pp. 387-390. (In Bengali)

13. Demir, I.; Ermis, S. Effect of controlled hydration treatment on germination and seedling growth under salt stress during development in tomato seeds. Eur. J. Hortic. Sci. 2003, 68, 53-58.

14. Demir, I.; Okcu, G. Aerated hydration treatment for improved germination and seedling growth in aubergine (Solanum melongena) and pepper (Capsicum annuum). Ann. Appl. Biol. 2004, 144, 121-123. [CrossRef]

15. Di Girolamo, G.; Barbanti, L. Treatment conditions and biochemical processes influencing seed priming effectiveness. Ital. J. Agron. 2012, 7, 178-188. [CrossRef]

16. Bekendam, J.; Grob, R. Hand Book for Seedling Evaluation, 3rd ed.; International Seed Testing Association (ISTA): Zurich, Switzerland, 2003; p. 143.

17. Othman, Y.; Al-Karaki, G.; Al-Tawaha, A.R.; Al-Horani, A. Variation in germination and ion uptake in barley genotypes under salinity conditions. World J. Agric. Sci. 2006, 2, 11-15.

18. Czabator, F.J. Germination value: An index combining speed and completeness of pine seed germination. For. Sci. 1962, 8, 386-396.

19. Association of Official Seed Analysts. Seed Vigor Testing Handbook, 1st ed.; AOSA: East Lasing, MI, USA, 1983.

20. Baki, A.A.A.; Anderson, J.D. Viability and Leaching of Sugars from Germinating Barley. Crop Sci. 1970, 10,31-34. [CrossRef]

21. BARC. Fertilizer Recommendation Guide (FRG); Bangladesh Agricultural Research Council: Dhaka, Bangladesh, 2012.

22. Singh, H.; Jassal, R.K.; Kang, J.S.; Sandhu, S.S.; Kang, H.; Grewal, K. Seed priming techniques in field crops-A review. Agric. Rev. 2015, 36, 251-264. [CrossRef]

23. Ashraf, M.; Foolad, M.R. Pre-sowing seed treatment-A shotgun approach to improve germination, plant growth, and crop yield under saline and non-saline conditions. Adv. Agron. 2005, 88, 223-271.

24. Ghassemi-Golezani, K.; Sheikhzadeh, P.; Valizadeh, M. Effects of Hydropriming Duration and Limited Irrigation on Field Performance of Chickpea. Res. J. Seed Sci. 2008, 1, 34-40. [CrossRef] 
25. Farooq, M.; Basra, S.M.A.; Wahid, A.; Ahmad, N. Changes in nutrient-homeostasis and reserves metabolism during rice seed priming: Consequences for seedling emergence and growth. Agric. Sci. China 2010, 9, 191-198. [CrossRef]

26. Hepler, P.K. Calcium: A central regulator of plant growth and development. Plant Cell 2005, 17, $2142-2155$. [CrossRef] [PubMed]

27. Burstrom, H.G. Calcium and plant growth. Biol. Rev. 1968, 43, 287-316. [CrossRef]

28. Harper, J.F.; Breton, G.; Harmon, A. Decoding $\mathrm{Ca}^{2+}$ signals through plant protein kinases. Annu. Rev. Plant Biol. 2004, 55, 263-288. [CrossRef] [PubMed]

29. Omidi, H.; Soroushzadeh, A.; Salehi, A.; Ghezeli, F.A.D. Rapeseed germination as affected by osmopriming pretreatment. J. Agric. Sci. Technol. 2005, 19, 125-136.

30. Khan, M.Q.; Anwar, S.; Khan, M.I. Genetic variability for seedling Traits in wheat (Triticum aestivum L.) under moisture stress conditions. Asian J. Plant Sci. 2002, 1, 588-590. [CrossRef]

31. Harris, D.; Rashid, A.; Miraj, G.; Arif, M.; Shah, H. 'On-farm' seed priming with zinc sulphate solution-A cost-effective way to increase the maize yields of resource-poor farmers. Field Crops Res. 2007, 102, 119-127. [CrossRef]

32. Sadeghian, S.Y.; Yavari, N. Effect of water-deficit stress on germination and early seedling growth in sugar beet. J. Agron. Crop Sci. 2004, 190, 138-144. [CrossRef]

33. Sisodia, A.; Padhi, M.; Pal, A.K.; Barman, K.; Singh, A.K. Seed priming on germination, growth and flowering in flowers and ornamental trees. In Advances in Seed Priming; Springer: Singapore, 2018; pp. 263-288.

34. Rehman, H.; Nawaz, Q.; Basra, S.M.A.; Afzal, I.; Yasmeen, A. Seed priming influence on early crop growth, phenological development and yield performance of linola (Linum usitatissimum L.). J. Integr. Agric. 2014, 13, 990-996. [CrossRef]

35. Harris, D.; Joshi, A.; Khan, P.A.; Gothkar, P.; Sodhi, P.S. On-farm seed priming in semi-arid agriculture: Development and evaluation in maize, rice and chickpea in India using participatory methods. Exp. Agric. 1999, 35, 15-29. [CrossRef]

36. Harris, D.; Pathan, A.K.; Gothkar, P.; Joshi, A.; Chivasa, W.; Nyamudeza, P. On-farm seed priming: Using participatory methods to revive and refine a key technology. Agric. Sys. 2001, 69, 151-164. [CrossRef]

37. Gebreegziabher, B.G.; Qufa, C.A. Plant physiological stimulation by seeds salt priming in maize (Zea mays): Prospect for salt tolerance. Afr. J. Biotechnol. 2017, 16, 209-223.

38. Li, Y.J.; Dorna, H.; Guo, S.J.; Zhai, M.P. Effects of osmopriming and hydropriming on vigour and germination of China aster (Callistephus chinensis (L.) Nees.) seeds. For. Stud. China 2009, 11, 111-117. [CrossRef]

39. Harris, D.; Rashid, A.; Hollington, P.A.; Jasi, L.; Riches, C. Prospects of Improving Maize Yields with 'On-Farm' Seed Priming. Sustainable Maize Production Systems for Nepal; No. 631.536 RAJ; CIMMYT: Texcoco, Mexico, 2002.

40. Jisha, K.C.; Vijayakumari, K.; Puthur, J.T. Seed priming for abiotic stress tolerance: An overview. Acta Physiol. Plant 2013, 35, 1381-1396. [CrossRef]

41. Sharma, A.D.; Rathore, S.V.S.; Srinivasan, K.; Tyagi, R.K. Comparison of various seed priming methods for seed germination, seedling vigour and fruit yield in okra (Abelmoschus esculentus L. Moench). Sci. Hortic. 2014, 165, 75-81. [CrossRef]

42. Wojtyla, Ł.; Lechowska, K.; Kubala, S.; Garnczarska, M. Molecular processes induced in primed seeds-Increasing the potential to stabilize crop yields under drought conditions. J. Plant Phys. 2016, 203, 116-126. [CrossRef] [PubMed]

43. Waqas, M.; Korres, N.E.; Khan, M.D.; Nizami, A.S.; Deeba, F.; Ali, I.; Hussain, H. Advances in the concept and methods of seed priming. In Priming and Pretreatment of Seeds and Seedlings; Springer: Singapore, 2019; pp. 11-41.

Publisher's Note: MDPI stays neutral with regard to jurisdictional claims in published maps and institutional affiliations. 